\title{
The Role of Antonyms in Theoretical Mechanics
}

\author{
Gani Pllana \\ University of Prishtina "Hasan Prishtina", Republic of Kosova \\ Email:gani_pllana44@gmail.com \\ Sadete Pllana \\ University of Prishtina "Hasan Prishtina", Republic of Kosova \\ Email:sadetepllana@outlook.com
}

Doi:10.5901/ajis.2015.v4n3s1p29

\begin{abstract}
Antonymy being an important feature of everyday life, is present everywhere and occupies a place in society. In terminologies of different fields of knowledge there is a presence of antonyms, depending on the terminology of the field being studied. Antonym words are used in a scientific-technical style. In each antonym pair antonym words usually either are or appear implicit, they also meet the requirement that technical-scientific terms need. By entering a systematic link with other words of the vocabulary, antonyms perform the role of expression or of naming a thing, of a phenomenon and process, and can often serve also as the terms of a specific field of scientific and technical terminology. Such are for example anode and cathode (in the terminology of physics), concave - convex (in optics, etc.). In the field of theoretical mechanics we also come across a number of antonym terms, which will be addressed in this paper.
\end{abstract}

Keywords: the role of antonyms in terminology, antonyms, theoretical mechanics.

\section{Introduction}

Antonyms are different words with an opposite meaning. Antonyms are the most appropriate linguistic tools, through which man expresses the character of the opposite of things, the processes of complex phenomena in nature and society. This is the reason that led us to look at the role of antonyms in theoretical mechanics. The study of antonyms also relates to a matter of methodological character ${ }^{1}$, defined in the differentiation of words in counterpoint, which serves to observe their semantic side. Antonymy has long been treated by philosophers, psychologists, anthropologists, linguists, terminologists and lexicographers. Beside the handling of antonymy as a general lexicological phenomenon, in todays linguistics there is an increasingly prevalent trend for its deeper and finer exploration, as it appears in particular national languages in the world. Specific studies for antonymy in Albanian language are written about 1960 of the last century, when the Albanian Lexicology was created as a new science, with its true features of science.

Lexico-semantic links have one thing in common: They all have a single quality, the semantic dimension found in all languages and taught more easily through examples, rather than through theoretical explanations, such as the oldyoung, good-bad, top-down (alb. i vjetër-i ri, i mirë-i keq, lartë-poshtë) etc.

In Albanian Linguistics antonyms are relatively well studied. Suffice it to mention here the researchers, as $\mathrm{H}$. Pasho $^{2}$ for the terminology of economics, M. Samara, J. Thomas, R. Memushaj, J.. Lloshi, I. Goçi for the Albanian language ${ }^{3}$. M. Samara ${ }^{4}$ explains, that the antonym is a lexico-semantic opposite, while the opposition is a broader concept and expresses relations between words or other linguistic entities that are not Antonyms. With this definition we understand that the antonym connection between words is conditioned by their lexical meaning. Thus, for example, in the

\footnotetext{
${ }^{1}$ M. Samara, Çështje të antonimisë në gjuhën shqipe, ASHSH IGJL, Tiranë, 1985.

${ }^{2}$ H. Pasho, Terminologjia e ekonomisë në gjuhë shqipe nga Rilindja deri në vitet '80 të shek. XX, ASHSH IGJL, Tiranë, 2005

31. Samara, M. Fjalor i antonimeve në gjuhën shqipe, Shkup, 1998. 2. J. Thomai, Leksikologjia e gjuhës shqipe [Lexicology of Albanian], BOTIMET TOENA, Tiranë, 2006; 3. R. Memushaj, Hyrje në gjuhësi, DITURIA, Tiranë, 2002; 4. Lloshi, Xh. Stilistika dhe pragmatika, TOENA, Tiranë, 1999. 5. Goçi, I. Antonimet e gjuhës shqipe, IA, Prishtinë, 1985.

${ }^{4}$ Samara, M. Çështje të antonimisë në gjuhën shqipe [Antonymy issues in Albanian]., Tiranë, 1985. p. 41-55.
} 
pair fill-empty (oil of machine), we are dealing with counterpoint of meanings related to actions that are performed in opposite directions.

\section{Lexical Features of Antonyms}

Antonymy is a universal phenomenon, but with different features in different languages. Some researchers defend the thesis of the existence of the extremities or polarity between components of antonym pairs. ${ }^{*} \mathrm{M}$. Samara5 in his monograph states that in addition to the above features, there is also the property or the ability to have members of an antonymic pair to connect semantically the grammar and lexicon and grammatical terms they should be homogeneous; eg. the words sell (alb. shitje) and buy (alb. blej) do not belong to the same grammatical category and therefore, are not Antonyms.

Antonyms in Albanian language can be words:

- $\quad$ phonetically different good-bad; left-right, (alb. i mirë - i keq; majtas-djathtas);

- totally opposite in their setting up / down (ab. lart/poshtë)

- expressed with prefixes ( pure-unpure, possible-impossible, important-unimportant, possible-impossible)

- $\quad$ phraseological units with glove-without glove (alb. me doreza-padoreza) etc.

The distinctive feature of this antonymic group is, that the opposites label quality which compare ie. quality that can be conceived, therefore dimension or the level with which the pair associates has a medium and neutral measuring point, which Samara calls normë 5 .

\section{Semantic Features of Antonyms}

Lexical features of the term antonymy are not enough to classify it without mentioning semantic features which hold a specific place.

The semantic analysis ${ }^{6}$ of antonyms guarantees the opportunity to highlight the features of the antonymic pair, as well as the degree of opposition of its components. This can be achieved by performing a semantic analysis of antonymic words as well as their relation to other words. Antonyms associate with various forms with other elements of language. Precisely, these connections prompt the antonym to create meaning through context. For example, the word book (alb. libër) and table (alb. tavolinë) are not antonyms, as their meanings have no common seme; and the words cold / hot (alb. i ftohtë/i nxehtë) are antonyms, as they belong to the same semantic field, that of temperature, and enter antonymic rapports, according to the feature \pm hot (alb. \pm inxehtë).

\section{The Main Tasks of Scholars of the Antonymy}

Antonyms create in the consciousness of the speaker associative concepts according to contrast. Thus the word straight (straight trajectory) (alb. e drejtë (trajektore e drejtë) ) enters an antonym relationship with the word curved (curved trajectory) (alb. e shtrembër (trajektore e shtrembër)). The study of antonymy is closely linked to the study of polysemy, the synonymy and homonymy?

a. The first task which must be taken into account in determining the antonym in Albanian, is not the negative, but opposite character of the meanings of words and stable compound words, ie the ability of words to oppose each other in terms of their affirmative; This element of the affirmative is in antonym words with negative prefixes. (eg washed-unwashed; the washed wheel - the unwashed wheel) (alb. e larë-e palarë; te rrotë larë rrotë e palarë).

b. The second task is the semantic link that connects or brings together words or two limbs unites of an antonym pair with each other. Eg. words white-black, thin-thick, long- short, left-right, black - white (alb. e bardhë-e zezë, i hollë-i trashë, i gjatë- $i$ shkurtër, i majtët-i djathtë, i zi - $i$ bardhë) Words negative-positive (alb. negativpozitiv) relate antonymically by context, since the two opposite poles mark electricity (physics).

5 Samara, M. Çështje të antonimisë në gjuhën shqipe [Antonymy issues in Albanian]., Tiranë, 1985 p. 40.

6 Samara, M. Çështje të antonimisë në gjuhën shqipe [Antonymy issues in Albanian]., Tiranë, 1985, p. 44.

7 Pllana, G.: "Observations on antonyms in the field of thermo-technics" 4rd International Conference on Language, Medias and Culture - ICLMC 2015, April 9-10, 2015, in Kyoto, Japan. 
c. The third task of determining the antonym is the possibility of comparison between them from understanding; the possibility puts antonyms in an counteracting relationship. In this case we have greater clarity for adjective Example: and adverb antonyms which have greater use in the terminology of theoretical mechanics.

- Adjective antonyms:

close - distant, symmetry-asymmetry, rough - soft, white - black, equal - unequal, reconcilable - detachable, restricted - unrestricted, formless - regular, right - left, balanced - unbalanced, thin - thick strong - weak, open - closed, inactive - active, deep - shallow, definite - indefinite, demand - supply, despair - hope, dim - bright, disappear - appear, discourage - encourage, capable - incapable, clear - cloudy, decrease - increase, shortened - lengthened, damaged undamaged, rushed - slowed, buttoned - unbuttoned, dependent - independent, breakable - unbreakable, used - unused, unprotected - protected, defined - undefined, unscrewing - screwing (alb. i afërt - i largët, simetri - asimetri, i ashpër - i butë, i bardhë - i zi, i barabartë - i pabarabartë, i bashkueshëm - i ndashëm, i çrregullt - i rregullt, i djathtë - i majtë, i ekuilibruar- i çekuilibruar, i fortë - i dobët, i hapur - i mbyllur, i hollë - i trash, joaktiv-aktiv,i thellë - i cekët, kërkesë furnizim, zhgënjim - shpresë, i errët - i ndritur, zhdukem - shfaqem, dekurajoj - inkurajoj, i aftë - i paaftë, i pastër - i turrbullt, zbritje - ngritje, i pacaktuar - i caktuar, i padëmtuar - i dëmtuar, i pambrojtur - i mbrojtur, i papërdorur - i përdorur, i pathyeshëm - i thyeshëm, i rregullt - i parregullt, i shpejtuar - i ngadalësuar, i varur - i pavarur, i zgjatur - i shkurtuar, i zhdëmtuar - i dëmtuar, i zhvidhosur - vidhosur) etc.

- Adverb antonyms:

never - always, empty - full, inside - outside, internal - external, right - left, directly - indirectly, long - short, open closed, early - late, thin - thick, horizontally - vertically, wet - dry, high - down, loosely - tight, left - right, inside - outside, quickly - slowly, often - rarely, crooked - straight, vertically - horizontally, empty - full, curved - straight (alb. asnjëherë kurdoherë, bosh - plot, brenda - jashtë, brendazi - jashtazi, djathtas - majtas, drejtpërdrejt - tërthorazi, gjatë - shkurt, hapur - mbyllur, herët - vonë, hollë - trashë, horizontalisht - vertikalisht, lagët - thatë, lartë - poshtë, lirshëm shtrënguar, majtas - djathtas, përbrenda - përjashta, shpejt - ngadalë, shpesh - rrallë, shtrembër-drejt, vertikalisht horizontalisht, zbrazur - plotë, zhdrejtas-drejtas) etc.

Antonymy, different from multi meanings, and synonymy characterizes terminology for systemic connections of notions and for an advanced terminology in the system:

- $\quad$ Antonymic pairs that name action:

open - close (of the lid of the machine) (alb. hapje-mbyllje), reduction-proliferation (of oil) (alb pakësim-shtim i vajit), concentration-distraction (of the gear wheel) (alb. përqëndrim-shpërqëndrim (e rrotës dhëmbëzore)), blockingunblocking (of the mechanism) (alb. bllokim-zhbllokim ( i mekanizmit)).

- $\quad$ Antonymic pairs that name quality:

maximum-minimum (of the oil level) (alb. maksimum-minimum (i nivelit të vajit)), active-passive (wheel) (alb. aktive-pasive (rrotë)), retail-wholesale (oil lubrication) (alb. pakicë-me shumicë (lubrifikim vaji)), good - bad (mechanism) (alb. i mirë - $i$ keq (mekanizëm)), , small - large (Axis) (alb. i madh- $i$ vogël (aks)), hard- soft (metal) (alb. $i$ fortë-i butë (metal)).

- Antonymic pairs that name phenomenon:

balance-disbalance (equipment), equality - inequality, ebb and flow (alb. ekuilibër-desekuilibër (pajisje), barazipabarazi, baticë-zbaticë).

- Antonymic pairs that name conditions:

stability-instability, under limit - over limit, cold-hot (alb. qëndrueshmëri-paqëndrueshmëri, mbikufi-nënkufi, i ftohtë-i nxehtë).

- Antonymic pairs that name different notions in theoretical mechanics:

macrostructure-microstructure, density - sparsity, expansion - contraction (alb. makrostruturë-mikrostrukturë, mbitruysni-nëntrysni, dendësi-jodendësi, bymim-tkurrje).

Meanings of antonyms counter oppose usually in all compositions, but, nevertheless, they have a common composition of meaning that connects their opposing meanings like an axis, otherwise there could be no counterpoint: near-faroppose according to distance, and white - black by color (alb. $i$ bardhë - $i$ zi sipas ngjyrës), tall short by magnitude (alb. $i$ gjatë - $i$ shkurtër sipas një përmase), ascend - descend by movement in a vertical direction or steepness (alb. hipi - zbres sipas lëvizjes në drejtimin vertikal a të pjerrët) etc.

Reliable Antonyms, hard - soft, thick - thin, full - empty, outside - inside (alb. $i$ ashpër - $i$ butë, $i$ trashë - $i$ hollë, mbush - zbraz, jashtë - brenda) etc. 


\section{Antonyms with Prefixes in Theoretical Mechanics}

During the study of antonymy with prefixes we come across a few problems: if the opposition of lexical meanings that express antonym words with prefixes are justified on a semantic and structural side, on what level does this confrontation appear, complete or incomplete. The prefix as a formative element attaches to the theme in question ${ }^{8}$, by forming a new word that makes sense opposite to that of the word without the prefix.

Antonyms formed with the prefix of opposite meaning:

anti-: particle-antiparticle, adiabatic-antiadiabatic (alb. thërrmijë-antithërrmijë, adiabatik-antiadiabatik).

ç- (meaning 'i-'): i rregullt - i çrregullt (eng. regular - irregular) akord $j$-çakordoj

(eng. tune - untune), ekuilibroj - çekuilibroj (eng. poise-un-poise), rregullim-çrregullim (eng. adjust - un-adjust).

jo-: (meaning 'un-', 'non-', 'in-', 'i' and 'ab'): aftësi - joaftësi (eng. skill-unskilled), ekonomik - joekonomik (eng. economical - uneconomical), fitimprurës - jofitimprurës (eng. profitable - unprofitable), industrial - joindustrial (eng. intustrial - nonindustrial), kalimtar - jokalimtar (eng. transitional - intransitive), natyror - jonatyror (eng. natural unnatural), original - joorigjinal (eng. original - unoriginal), përdorues - jopërdorues (eng. usable - unusable), praktik jopraktik (eng. practical - unpractical).

mos-barazi-mosbarazi. (eng.non-equity-disparity).

pa-: (meaning 'without', '-less' and 'un-'): i besueshëm-i pabesueshëm (eng.reliable - unreliable), i caktuar- $i$ pacaktuar (eng. set/defined-undefined), i dëmshëm- i padëmshëm (eng. harmful-harmless),i dobishëm- i padobishëm (eng.useful - useless), fuqi- pafuqi (eng. strength-without strength (impotent), i fuqishëm- i pafuqishëm (eng. powerfullpowerless), i harxhuar- i paharxhuar (eng.consumed - unconsumed), i konsumuar- i pakonsumuar (eng. consumated unconsumated), i qëndrueshëm- i paqëndrueshëm (eng. stable-unstable);

s-saktësi-pasaktësi. (eng. exactly-inaccuracies.)

sh-fuqizoj-shfuqizoj. (eng. empower- un-empower)

zh- (meaning 'to undo smth' using 'un-' or 'de-'): bllokim - zhbllokim (eng. block - unblock), dëmtim - zhdëmtim (eng. injury/damage-compensation), vlerësim - zhvlerësim (eng. evaluation/devaluation).

\section{Conclusion}

We note that antonyms are words from the general vocabulary, but which enter the composition of the mechanical theory vocabulary and create new terms, such as: regular-irregular (regular mechanism - irregular mechanism) (alb. $i$ rregullt-i çrregullt (mekanizëm i rregullt - mekanizëm i çrregullt), straight - crooked(right prong - awry/curved prong) ), (alb. i drejt $i$ shtrembër (dhëmbëzor i drejtë - dhëmbëzor i shtrembër), small-large (small shaft - large shaft) (alb. $i$ vogël-i madh (bosht i vogël - bosht i madh)) etc.

Relilable and commonly used antonyms are usually words with different roots, egthin - thick (thin belt - thick belt) (alb. $i$ hollë - i trashë (rrip i hollë - rrip i trashë)), small - large (small wheel - big wheel) (alb. e vogël - e madhe (rrotë e vogël - rrotë e madhe)), open - closed (lid of the machine) (alb. hap - mbyll (kapakun e makinës) ) etc. The opposite meanings of some of these antonyms fully exclude each other, usually in between them it is not possible to add any other intermediate limb. Some of these antonym words stand opposite one another as two half spheres, which in their negative or positive rapport form a whole (sphere), and are therefore also called complementary antonyms, eg jashtëm - i brendshëm (Eng. external - internal) (ngërthim i jashtëm external gearing/meshing- ngërthim i brendshëm internal gearing/meshing), negativ - pozitiv (pol) etc.

In view of the alignment, the phenomenon of the antonymy occurs more in words that express notions of feature, notions of time, space and quantity Well, antonyms in theoretical mechanics are adjectives and adverbs mainly.

From the view of theoretical mechanics terminology in this regard, in the emergence of semantic phenomena, it results that these lexico-semantic processes, affect the terminological lexicon as well.

\section{References}

Buckch, H. (1976). "Getriebewörterbuch- Dictionary of mechanisms”, Bauverlag GmbH-Wiesbaden und Berlin.. Duro, A. (2009) Termi dhe fjala në gjuhën shqipe [Term and word in Albanian]. Tirana: Fan Noli. 
Dhrimo, A., \& Memushaj, R. (2011). Fjalor drejtshkrimor i gjuhës shqipe [Albanian Orthographic Dictionary]. Tirana: INFBOTUES.

"Fjalor i termave themelorë të mekanikës-Dictionary of basic terms of mechanics", Tiranë, 2002.

Memushaj, R. (2004). Hyrje në gjuhësi [Introduction to Linguistics]. Tirana: DITURIA.

Pllana, S. (2003). Një analizë e metodave të punës praktike të terminologjisë [An analysis of practical methods of terminology]. TEKNIKA Revistë profesionale dhe shkencore për teori dhe praktikë, [TEKNIKA-Professional

and scientific journal for theory and practice], Year I, no. 3, 35-44. Ferizaj: University of Prishtina, Technical High School Ferizaj.

Pllana, G., \& Pllana, S. (2012). A conceptual connections on a word and term level in the terminology of theoretical mechanics (in Albanian and English). trans\&MOTOAUTO'12 20th International scientific and technical Conference on transport, road-building, agricultural, hoisting \& hauling and military techniques and technologies, Varna, Bulgaria.

Pllana, S., \& Pllana, G. (2012). Studies undertaken in the field of terms and coverage mechanics as its respective glossary of the Albanian language. trans\&MOTOAUTO'12 20th International scientific and technical Conference on transport, road-building, agricultural, hoisting \& hauling and military techniques and technologies, Varna, Bulgaria.

Pllana, G. (2015). "Observations on antonyms in the field of thermo-technics" 4 rd International Conference on Language, Medias and Culture - ICLMC 2015, April 9-10, 2015, in Kyoto, Japan.

Sager, J. (1990). A practical course in Terminology Processing. Amsterdam, Philadelphia: John Benjamins.

Samara, M. (1985). "Çështje të antonimisë në gjuhën shqipe” [Antonymy issues in Albanian]. Tirana: Academy of Sciences of Albania.

Thomaj, J. (2006). Leksikologjia e gjuhës shqipe [Lexicology of Albanian]. Tirana: BOTIMET TOENA. 